\title{
The Palimpsest of River-Floodplain Management and the Role of Geomorphology
}

\author{
Paul F. Hudson and Hans Middelkoop
}

\begin{abstract}
Embanked floodplains are the status-quo where humans are a major component of the environment, especially across Europe and North America. Effective management of embanked rivers requires a comprehensive knowledge of past and present-day geomorphic processes, including sediment transport and channel and floodplain dynamics. Many approaches to management include activities and modifications which take into account past natural and human impacts and management decisions, resulting in a palimpsest of river and floodplain management. A synthesis of 12 diverse case studies provides evidence of the palimpsest in river-floodplain management, and illustrates four key roles for geomorphology in the design of effective management strategies, including (1) regional and longerterm context, (2) system evolution and past human impacts, (3) engineering design and management options, and (4), environmental and geomorphic restoration as an end-product. A review and comparison of heavily managed embanked rivers spanning a range of climatic and geomorphic provinces across North America and Europe illustrate the role of geomorphology in this palimpsest and its value to integrated management.
\end{abstract}

Keywords Fluvial geomorphology - River dynamics · Palimpsest - Embanked floodplains $\cdot$ Integrated floodplain management

\section{The Management Palimpsest}

River and floodplain management of the active system is superimposed upon the impacts and structures of natural channel and floodplain development, and older forms of engineering and management, either in conceptual design or actual physical space. In many cases, the present-day state of the river has not reached an equi-

\footnotetext{
P. F. Hudson $(\square)$

Leiden University, The Netherlands

e-mail: p.f.hudson@luc.leidenuniv.nl

H. Middelkoop

Department of Physical Geography, University of Utrecht, Utrecht, Netherlands

e-mail: h.middelkoop@uu.nl 
librium to past natural or human changes. Modern management is thus directly interacting with, and in some cases responding to, older management decisions imposed upon the system at either the local (e.g., channel reach) or basin scale. This sequential "layering" of steps of natural evolution and management in which each new layer interacts with the impacts of the previous is hereby conceptualized as a "palimpsest" of river-floodplain management (Fig. 1a). The concept of palimpsest in geomorphology has gained attention during the past decade in view of renewed attention to interpretation of landscape evolution within the anthropocene context (Goudie and Viles 2010; Cotterhill and De Witt 2011; Knight 2012; Von Elverfeldt 2012). Here, we present the palimpsest as a stack of forcings, with the lower representing tectonics/subsidence, and then subsequently followed by climate, land cover change (natural and human-induced), past engineering, and the top layer representing the restoration actions (Fig. 1). Each of these layers may be represented as a conveyor belt of infinite length, and one belt is resting upon (and thus moved laterally) by the underlying belt. Each belt drags the fluvial system laterally, along a dimension that represents its state, varying from wide braided, meandering to narrow and deep channelized rivers. A shifting belt may represent an ongoing forcing such as tectonic subsidence or a long-term response (Fig. 1a), e.g., long-term river adjustment to climate change or river damming (Fig. 1b). The intensity of the forcing or the river response is represented by the velocity at which the belt runs. Different forcings may push the river towards different states, represented by alternating movements of the belts. Over time, the direction of movement may even change, for example, under varying climate forcing. As belts may shift in opposite directions, the final lateral movement of the system state, being positioned on the top layer, depends thus on a combined and dynamic evolution of the system (Fig. 1c). Thus, this perspective is more dynamic and complex than a simple "inheritance" view, which suggests a static "base" status as the initial condition for the subsequent stage in river evolution. In addition, it is more dynamic and less "tidy" than the symmetrical goal often pursued by government agencies (Fig. 1d). Such a static approach neglects that multiple forcings act over different time scales while delayed responses of the fluvial system results in a "stacked inheritance" of changes, and not solely states.

This interpretation of a floodplain geomorphic palimpsest acknowledges therefore that management and human activities are continuously being overlaid upon an adjusting fluvial system to various past forcings. Although the human-associated forcings (land use change, past engineering) had their intrinsic aims (e.g., agriculture, collecting water for irrigation), many — or even most—impacts on the fluvial system were unintended. For example, the Bronze Age people who cleared forest in the upper Rhine basin for agriculture certainly did not intend to cause accelerated sediment deposition in the Rhine delta (cf. Middelkoop et al. 2010), neither did the reservoir builders aim at drowning a downstream delta. It is only the top belt, representing restoration management that aims at dragging the river towards a desired state, and often less than a pristine state. The concept of the management palimpsest can be imagined by means of floodplains, for example, along a river in a subsiding basin that has changed to a meandering style after the last glacial, and where its ongoing 
overbank deposition is interrupted due to embankment. Renewed channel-overbank interactions will occur after dike removal, but future deposition amounts still depend on the river's sediment load and accommodation space associated with climate and tectonics, respectively. Thus, any approach to river management is engaged with a physical system that has already undergone prior attempts at management.

The impacts of historic human activities and management approaches on the fluvial system vary according to scale and magnitude. But each discrete form of management that influences actual geomorphic processes requires certain timescales to unfold, which is spatially dependent (see chapter "Impact Scales of Fluvial Response to Management Along the Sacramento River, California, USA: Transience Versus Persistence"). In addition, while each management action may have a specific life-span, such as in the case of a meander bend cutoff or groyne construction, its legacy remains physically part of the river and floodplain environment in which subsequent management must engage. Excellent examples are provided by the extensive documented management chronologies of the Mississippi and Rhine Rivers (Hudson et al. 2008), which include specific impacts which are common to many managed river systems across North America and Europe.

\section{The Role of Geomorphology}

The 12 diverse case studies provided in the preceding chapters provide evidence of the above described palimpsest in river management and demonstrate four key stages in which geomorphology plays a vital role in the design of effective river management strategies to account for this palimpsest. These include, (1) regional and longer-term context, (2) system evolution and impacts of past human actions, (3) design of engineering structures and management options, and (4) environmental restoration as an end-product.

\subsection{Regional and Longer-Term Past Context}

The regional context provides background information on the past evolution of the system represented by the bottom belts (tectonics, climate, land use) in Fig. 1, which cannot be obtained from direct instrumentation, and which may require long timescales to detect. A prime example includes subsidence and neotectonic controls, which slowly induce shallow warping of floodplain surfaces. Such influences result in small amounts of incremental change over short (e.g., annual) time-scales, but result in significant changes to the floodplain topography and drainage (e.g., Guccione et al. 2002) over long time-scales. The importance of this is appreciated along the Red River of Manitoba (see chapter "Flooding, Structural Flood Control Measures, and Recent Geomorphic Research Along the Red River, Manitoba, Canada"), where subsidence of Pleistocene deposits influences the modern river valley gradient associated 

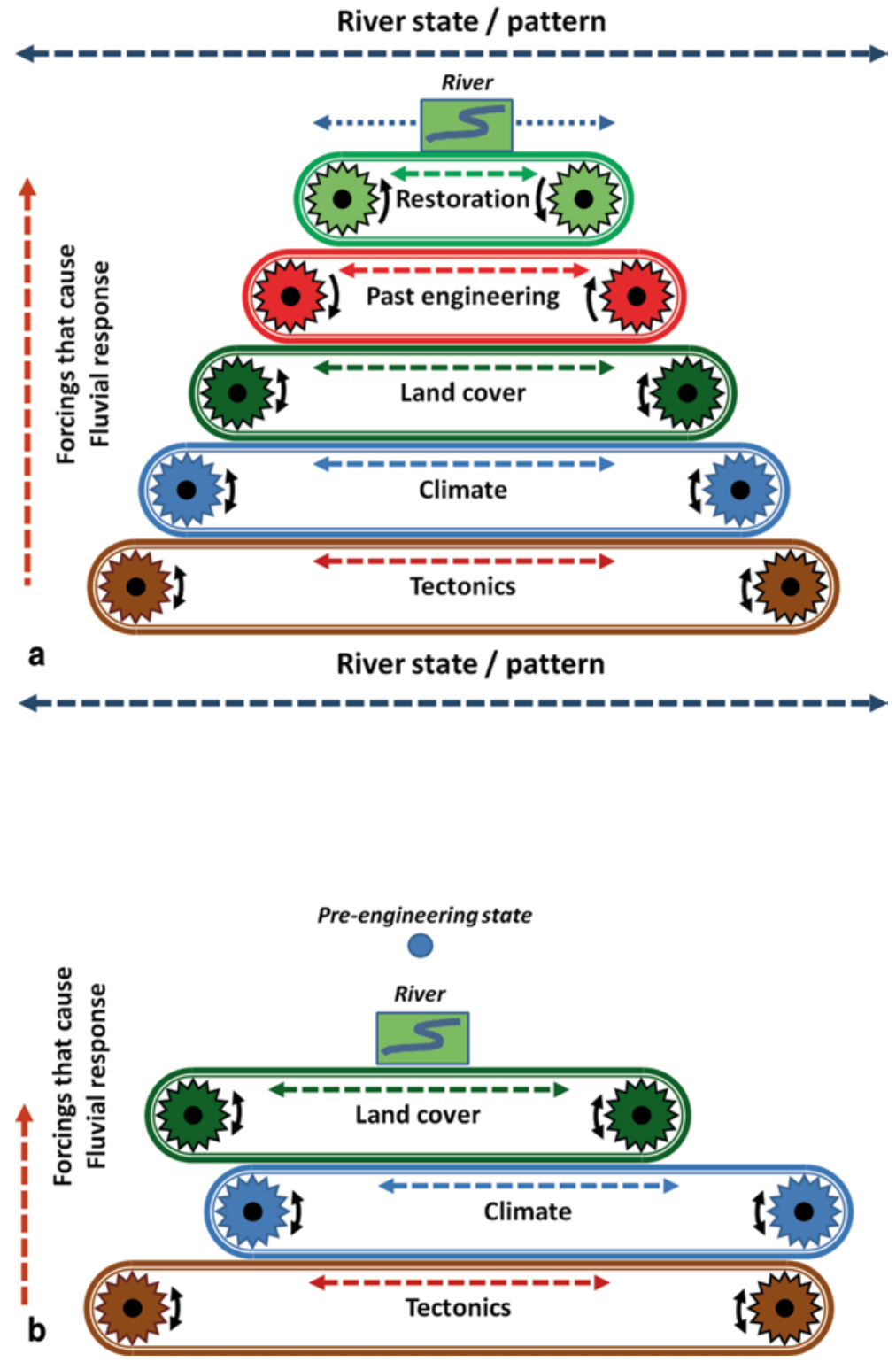

Fig. 1 a The palimpsest of river-floodplain management, represented as a stack of conveyor belts, each representing a different type of forcing and fluvial response, driving the river across different states, b Underlying belts represent natural (often slowly proceeding) forces and responses, $\mathbf{c}$ Past engineering may have caused a significant-still progressive-state disturbance, $\mathbf{d}$ River restoration is the top belt to move the river towards a desired state - while the underlying belts remain to turn 


\section{River state / pattern}
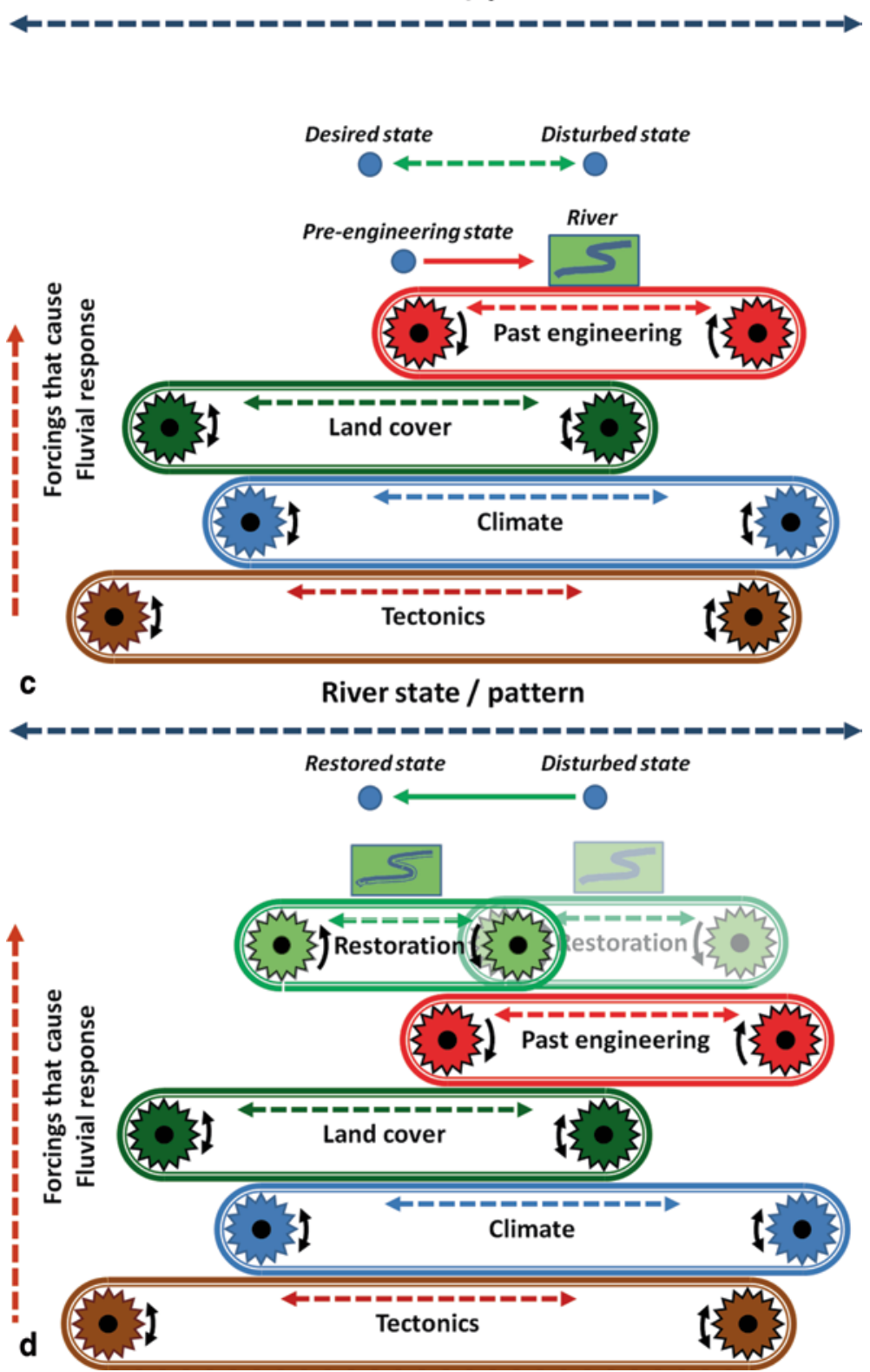

Fig. 1 (continued) 
with the high flood frequency. Likewise, restoration plans for the Rhône River should consider the fact that the valley has been greatly influenced by climate and land cover change since the last deglaciation, affecting discharge and sediment load, and driving the river to create its fluvial landscape that later became occupied and modified by humans (see chapter "Historical Development and Integrated Management of the Rhône River Floodplain Between the Alps and the Camargue Delta, France").

\subsection{System Responses to Prior Human Activities and Management}

It is well established that many river basins in Europe and North America are heavily impacted by historic human activities. Although European basins have been significantly impacted by humans for a much longer period of time, there is also a longer record available to reconstruct the impacts of human disturbances and management. If restoration measures are to have an opportunity to be successful underlying natural dynamics and sensitivity of the various modes of the fluvial system must be understood (e.g., Schumm 1991). A key issue requires an assessment of the impacts of past human activities to the contemporary system (see chapter "Historical Development and Integrated Management of the Rhône River Floodplain Between the Alps and the Camargue Delta, France"). As much as possible, the goal should be to specifically address what was the impact of engineering and management to specific modes of the fluvial system, including sediment, discharge, channel dynamics, and floodplain adjustment (e.g., see chapter "Impact Scales of Fluvial Response to Management Along the Sacramento River, California, USA: Transience Versus Persistence").

\subsubsection{Sediment}

Changes in sediment load are a dominant control of river response, since the sediment forms the river's building material for morphologic adjustment (Church 2006; Gomez 2006; Knighton 1998; Meade and Moody 2010). Therefore, any plan at integrated river management must consider the sediment regime, and bed material load in particular (see chapter "Sand and Gravel on the Move: Human Impact on Bed-Material Load Transport in the Lower Rhine River"). Yet, sediment discharge in rivers adapting to changed boundary conditions or human impact may show considerable changes when compared to an equilibrium, unaffected situation. Accordingly, channel modifications have profound and long-term impacts on sediment transport and deposition.

Human impacts to sediment load and linkages with channel change are observed where main-stem dams have been imposed on the channel. Although the role of downstream sediment starvation has been widely recognized (e.g., Syvitski et al. 2005), the awareness of this upstream-downstream relation remains crucial for the development of a comprehensive understanding of the downstream impact of dams 
on alluvial rivers (Graf 2006). Reservoir trapping not only reduces sediment fluxes to drowning deltas, but also may result in a reduction in the size of channel bars and still progressive channel-bed incision, such as demonstrated for the Lower Volga (see chapter "Post-Damming Changes in Channel Morphology and Floodplain Inundation of the Lower Volga River") and the heavily dammed and engineered Ebro River in Spain (see chapter "Channel Responses to Global Change and Local Impacts: Perspectives and Tools for Floodplain Management (Ebro River and Tributaries, NE Spain)")).

The lower Rhine River provides an ideal case study because of the rich data set of sedimentary measurements, as well as the extensive documentation of the timing and dimensions of specific types of engineering impacts (Nienhuis 2008), common to many intensively modified rivers. Past engineering of the Rhine River (Kalweit 1993) has not only changed the volume of bed load transported by the river, but also the style of sediment transport changed, and the particle size has become coarser (see chapter "Sand and Gravel on the Move: Human Impact on Bed-Material Load Transport in the Lower Rhine River").

The linkage between changing sediment load and fluvial adjustment should not be overly simplified. In nearly all cases, river impoundments which result in changes in sediment load frequently concur with other human impacts being imposed on the system, such as land-use change, channel engineering, and flood control. Thus, while it may be straight forward to understand the direct impact of dams to sediment load and channel morphology immediately downstream of a dam ("locally"), it remains much more challenging to untangle cause and effect relationships between sediment load, altered discharge regime, and fluvial adjustment with increasing distance and fluvial complexity (see chapter "Impact Scales of Fluvial Response to Management Along the Sacramento River, California, USA: Transience Versus Persistence").

\subsubsection{Channel Changes}

Other than large main-stem dams, channel straightening and engineering for the sake of flood control and ship navigation is a direct human impact imposed on rivers (Gregory 2006). Such changes to channel morphology and hydraulics have the potential to influence channel incision, sediment transport, alluvial aquifers, floodplain processes, and to adversely impact a host of aquatic ecological processes. Direct channel engineering, often involving cut-offs and channel straightening, was a preferred method of flood control from the late-nineteenth to middle-twentieth centuries in North America. The Kissimmee River in subtropical Florida, for example, underwent extensive draining and straightening (see chapter "Geomorphic Perspectives of Managing, Modifying and Restoring a River with Prolonged Flooding: Kissimmee River, Florida, USA") since the 1880s, and artificial meander cut-offs in the 1930s. Further flow structures in the 1960s virtually canalized and radically changed the hydraulic geometry of this once unique meandering river floodplain system.

Examining channel changes over long-time periods reveals not only changes in channel pattern, but also their linkage to specific types of floodplain environ- 
ments (e.g., see chapter "Historical Development and Integrated Management of the Rhône River Floodplain Between the Alps and the Camargue Delta, France"; see chapter "Fluvial Geomorphology: Its role in Policy and Management Decisions on the Mississippi River Floodplain"). This is increasingly important because the emphasis on river and floodplain restoration frequently assumes a natural base-line for establishing restoration and management goals (Walter and Merritts 2008). In this context the Rhône River represents an ideal example because of the well-documented legacy of human impacts and recorded changes in channel morphology. In contrast to prior ideas, Bravard and Guyout (see chapter "Historical Development and Integrated Management of the Rhône River Floodplain Between the Alps and the Camargue Delta, France") illustrates how the natural channel of the Rhône had a braided pattern over much of its length since about the mid-Holocene. While the channel pattern adjusted to alternating sediment and discharge regime, the meandering pattern that currently dominates the Rhône River should be seen as an artificial legacy of river engineering, as it primarily developed since about the mid-1800s following engineering works to reduce erosion and create a navigable channel.

\subsubsection{Floodplains}

The alterations of floodplains associated with embankment frequently results in an overall disconnection of natural channel-floodplain interactions, often causing degradation of physical aquatic habitats. In combination with upstream damming and channel modifications, impacts may become more severe. River incision, whether caused by upstream dams and sediment starvation or by meander cut-offs and channel straightening, fundamentally alters floodplain hydrology. Most commonly this is manifest as a reduction in the frequency and duration of floodplain inundation, which has important consequences to riparian ecosystems. For example, while the natural flood regime of the Kissimmee River was annually associated with several months of overbank inundation, the impacts of engineering abruptly reduced the flood pulse frequency and duration, which had subsequent profound consequences to aquatic ecosystems associated with the extensive floodplain wetlands (see chapter "Geomorphic Perspectives of Managing, Modifying and Restoring a River with Prolonged Flooding: Kissimmee River, Florida, USA"). The lower Danube provides an interesting perspective (see chapter "Embanking the Lower Danube: From Natural to Engineered Floodplains and Back"), as it has undergone a reduction in sediment supply and a reduction in floodplain inundation because of large mainstem dams, floodplain embankment and other structural flood-control measures. In addition to adverse impacts to the floodplain habitat, the reduction of the flood pulse has consequences to the floodplain biogeochemistry, as illustrated by the example of the Lower Mississippi River (see chapter "Managing the Mississippi River Floodplain: Achieving Ecological Benefits Requires More than Hydrological Connection to the River"), where reduced exchange between the channel and floodplain has strongly impacted floodplain fisheries. 


\subsection{Design and Calibration of Management Options}

Prior engineering pushed rivers into a disturbed state (Fig. 1c) while river restoration aims at bringing the system back towards a desired-more natural-state. In terms of the conveyor belt model, this requires adding a top belt that turns the river towards that new state (Fig. 1d). The model of turning belts remains valid because the underlying belts may continue to move. Additionally, the top restoration belt means that the new restoration measures will not result in a static future condition. In this scenario the river will continue to adjust over time. Thus, restoration plans should be aware of the continued movement of the underlying belts as well as that their measures will have an effect as represented by a new belt. Geomorphologists and ecologists are well aware that intricate and comprehensive knowledge of active geomorphic processes is essential not only for the proper design and operation of engineering structures, but also for planning a range of management options. Channel engineering operations, such as dredging, groyne placement, and bank protection (revetment) measures require knowledge of the interrelations between channel hydraulics and sediment transport, especially bed material (Gomez 2006). Similarly, the opening of flow diversion structures to reduce flood risk or to manage floodplain wetlands requires an understanding of suspended sediment dynamics, in addition to complex flood basin hydraulics and floodplain sedimentology (e.g., Nittrauer et al. 2012). Moreover, when adopting more recently proposed approaches of "building with nature" as advocated in the Netherlands (e.g., De Vriend et al. 2014), a thorough knowledge of processes and requisite skills in predicting the impacts of measures that promote natural processes is indispensable to effective floodplain restoration.

Sediment management should be a key issue in considering the design and restoration of rivers for sustainability, from the perspective of economic activities and nature. For the purpose of reducing the downstream impact of dams, a measure gaining in use is the downstream flushing of sediment trapped within reservoirs. The procedure is complex to implement, depending largely upon the configuration and morphology of the river valley, sediment type, as well as the dam and reservoir operation and design (Asaeda et al. 2014). Experiences along the Rhône River, for example, have been somewhat effective at reducing the impact of hungry water. Experiences along the Colorado River (Arizona), were introduced in the mid-1990s, and while less effective at restoration, are seen as a necessary component of the management schema. From the standpoint of managing the lower Rhine bed material load, although dredging is necessary in some reaches, other reaches require that bed sediment be moved by ships and dumped into river reaches undergoing incision. This "surgical" system of sediment management is feasible in a river such as the Rhine, as well as a number of intensively utilized rivers in North America and Europe, but is impractical for rivers that do not serve such an important economic function.

Although considerable attention is currently being paid to "soft" engineering approaches, hard engineering structures continue to have an important role in the management of embanked river systems, especially as regards flood risk reduction, or to serve as "hard" boundary conditions for "soft" restoration measures. Flow 
diversion structures which route flood waters beyond the embanked floodplain, for example, remain an essential component of managing flood risk in North America. For the Red River of Manitoba (see chapter "Flooding, Structural Flood Control Measures, and Recent Geomorphic Research Along the Red River, Manitoba, Canada"), structures were engineered to establish a flow diversion system to bypass urban areas. Research by Singer (see chapter "Impact Scales of Fluvial Response to Management Along the Sacramento River, California, USA: Transience Versus Persistence") considers how the opening of such structures locally influences sediment transport and channel adjustment along the Sacramento River, as well as overbank sedimentation. Along the lower Mississippi River, a fundamental component of the flood management plan includes flow diversion structures activated at specific discharge (stage) magnitudes, and these structures are also being utilized for the restoration of adjacent wetlands (Nittrouer et al. 2012). The placement and operation of flow diversion structures, however, should take into account reach-scale variation in hydraulics and sediment transport processes, because ultimately this influences the quantity and grain size of overbank sedimentation. This is observed for the Bonnet Carre flow diversion structure along the Lower-most Mississippi, which results in sand deposits that approximates sedimentation of former natural crevasse processes (see chapter "Fluvial Geomorphology: Its role in Policy and Management Decisions on the Mississippi River Floodplain").

\subsection{Ecosystem Restoration and Geomorphology as an End-Product}

The above examples serve to reinforce the position that in addition to natural forcings humans have imposed a multitude of actions that have impacted - and degraded - fluvial systems, by their sediment load, discharge regime, channels, and floodplains. The result of these modifications - many of which are imposed by the old "hard engineering" approaches - are fluvial systems that are very different from natural systems, but yet represent the status quo for environmental managers. While every river is different, it is the case that a number of these modifications have resulted in rather signature impacts, such that they suggest certain measures for management and restoration. It is therefore informative to consider those measures which have been successful, and to consider their potential for having a larger role in integrated management and restoration.

The concept of integrated river management is often depicted as a world in which rivers are free to erode, migrate, and flood. As integrated river management becomes an increasingly entrenched paradigm, even in North America, what is the role of classical hard engineering measures? Clearly many fluvial systems are simply unable to return to a natural status, as the space is not available and the upstream boundary conditions have been drastically altered by land use change and impoundments. In such cases classical hard engineering approaches remain important, at least to create an opportunity to locally "re-activate" fluvial processes. In this case flow diversion structures can also serve an important function 
of reconnecting floodplains with sediment and nutrient rich flood waters, such as along the lower Sacramento River basin of California (see chapters "Promoting Atmospheric-River and Snowmelt Fueled Biogeomorphic Processes by Restoring River-Floodplain Connectivity in California's Central Valley" and "Impact Scales of Fluvial Response to Management Along the Sacramento River, California, USA: Transience Versus Persistence").

Although the engineered diversion structures provide some measure of connectivity with the original floodplain, their limited extent and hydraulic conditions make them less likely to restore floodplain wetlands. An alternative approach may be intentional levee breaks for lower magnitude events, such as are occurring along the lower Sacramento Riverbasin (see chapter "Promoting Atmospheric-River and Snowmelt Fueled Biogeomorphic Processes by Restoring River-Floodplain Connectivity in California's Central Valley"). These structures closely mimic natural crevasse events in scale and function, and provide important topographic, sedimentologic, and hydrologic (i.e., as crevasse splays) variability along the floodplain, which is preferred for enhancing biodiversity. The Kissimmee River's extensive and expensive restoration project has become an important case study of US river restoration and integrated management (see chapter "Geomorphic Perspectives of Managing, Modifying and Restoring a River with Prolonged Flooding: Kissimmee River, Florida, USA"). A hallmark of the project is to reactivate the old meander bends which had been cutoff when the river was canalized, and to set the levees (dikes) back to encourage a broader zone of inundation. Early results are promising, as sedimentologic and hydrologic data suggest reconnected cutoffs are functioning as natural channels, and ecosystem services have been enhanced.

Management and restoration of large embanked floodplains is ultimately coordinated and implemented by government agencies. Among the most controversial actions associated with integrated floodplain management is the use and acquisition of floodplain lands and associated water bodies by government entities for the purpose of floodplain inundation and nature restoration. The process of land acquisition is expensive, and legally complex. Some management and restoration options require a specific knowledge of property ownership, whereby determination of ownership legally depends upon an understanding of the origin of a floodplain water body (see chapter "Fluvial Geomorphology: Its role in Policy and Management Decisions on the Mississippi River Floodplain"). The potential for floodplain management to actually be implemented then becomes dependent upon the appropriate legal interpretation of the formative processes of floodplain water-body construction. For this reason, a new form of management is being proposed for floodplain restoration in the Netherlands (floodplain stewardship council; Fliervoet et al. 2013), which would replace the presently responsible parties including water boards and government institutes at national, provincial and municipal levels. Conversely, when the river-floodplain system is allowed to be morphologically active and changing, legislation should accommodate regulation of ownership and maintenance obligations of newly formed features, such as channel bars, secondary channels, and floodplain lakes. This is not a new issue: Along the lower Rhine in the Netherlands there were established legislative criteria already in the seventeenth and eighteenth century 
to decide whether or not a newly formed channel bar would belong and become possession of the owner of the adjacent floodplain. The law stated that the adjacent floodplain land owner would gain legal possession only if the separating channel was too shallow to allow passage of a boat of specified dimensions (Hesselink 2001). Nevertheless, to allow creating and maintaining a more dynamic environment in the future, legislation should be coordinated with geomorphic processes and concepts (e.g., see chapter "Fluvial Geomorphology: Its role in Policy and Management Decisions on the Mississippi River Floodplain”).

\section{Contrasting Continental Visions to Managing Rivers for Climate Change?}

The case studies provided by this volume represent a continental perspective to consider different approaches to river and floodplain management and restoration, and for being prepared to cope with various climate change scenarios. Management along large alluvial rivers in Europe and North America contrasts sharply in its management vision. In terms of the implementation of strategies that are prepared to cope with climate change, the U.S. is in its infancy. A reliance on hard engineering approaches and the political difficulty (especially along rivers in some states) to incorporate alternative approaches, such as increasing the area of the embanked floodplain, makes a "room for the river" plan exceedingly difficult to implement (U.S. Army Corps of Engineers 2012). In comparison to Europe, the North American approach to floodplain management is more fragmented (National Research Council 1995, 2005), and less flexible to adapt to varying climate change scenarios. This is not to state that environmental river management does not have its success stories in the U.S, as there are many discreet cases of effective management which enhances river environments. The example of the Kissimmee River in Florida (see chapter "Geomorphic Perspectives of Managing, Modifying and Restoring a River with Prolonged Flooding: Kissimmee River, Florida, USA"), should certainly be upheld. Additionally, the science of dam removal has accelerated greatly over the past decade, and is being led by government agencies. These sucesses are in part because of greater attention to the dependence and interconnectedness of ecological river habitat to the geomorphic dimensions of rivers, as championed by Graf (2005, 2006) in regards to the "physical integrity" of rivers. Many large river basins in the U.S., however, lack a basin-scale perspective for coping with projected regional climate change scenarios. The enormous lower Mississippi, for example, has yet to have a specific approach for coping with climate change, although major tributary basins, including the Ohio, Missouri, and upper Mississippi River have conducted studies and initiated pilot studies (see chapter "The Role of Floodplain Restoration in Mitigating Flood Risk, Lower Missouri River, USA").

In contrast to North America, Europe in the 1990s underwent a significant paradigm shift in its vision for river and flood management (e.g., Kondolf 2012), away from a primary reliance on traditional "hard" engineering for flood control, 
towards "integrated flood management" with "soft" landscaping measures for nature restoration. While these measures were not necessarily implemented to cope with specific climate change projections, they included two important tenets. First, they approached river management from a basin-scale perspective, and, secondly, they viewed management for nature as being complementary with preparation for climate change. The approach to flood and environmental river management in Europe was solidified in two major continental-scale legislative acts passed by the European Union, namely the Water Framework Directive (2000) and the Floods Directive (2007/60/EC). Although implementation of the directives has not been uniform across the EU, and in particular some Eastern European nations (e.g., the Polish situation), it can be stated that the EU shares (mainly) a common vision, and has a "general" goal in mind as regards river management. Within the Rhine basin in Germany and the Netherlands, for example, substantial modifications have been made to embanked floodplains and river channels which required soft and hard (e.g., structural) approaches for the purpose of accommodating larger flood magnitudes and nature enhancement, which also is seen as preparing the fluvial system to better cope with climate change. Still, such management actions are expensive and complex to implement, requiring a geomorphologic assessment to provide a context for interpreting changes in rates and magnitude of channel adjustment, such as river migration, and ultimately to apply the appropriate model of restoration.

Acknowledgments We thank Maarten Kleinhans for constructive comments related to the concept and figure depicting the river-floodplain management palimpsest.

\section{References}

Asaeda, T., Rashid, M. H., \& Sanjaya, H. L. K. (2014). Flushing sediment from reservoirs triggers forestation in the downstream reaches. Ecohydrology . doi:10.1002/eco.1513

Church M. (2006). Bed material transport and the morphology of alluvial river channels. Annual Review of Earth and Planetary Sciences, 34, 325-354. doi:10.1146/annurev. earth.33.092203.122721.

Cotterhill, F. P. D. \& De Witt, M. J. (2011). Geoecodynamics and the Kalahari Epeirogeny: Linking its genomic record, tree of life and palimpsest into a unified narrative of landscape evolution. South African Journal of Geology, 114, 489-514.

De Vriend, H. J., Van Koningsveld M., Aarninkhof S. (2014). Building with nature: the new Dutch approach to coastal and river works. Proceedings of the ICE-Civil Engineering, 167(1), $18-24$.

European Council. (2000). Council Directive 2000/60/EC of the European Parliament and of the Council of 23 October 2000 establishing a framework for community action in the field of water policy. Official Journal of the European Union, 327, 22.12.2000.

Fliervoet, J. M., Van den Born, R. J. G., Smits, A. J. M. \& Knippenberg, L. (2013). Combining safety and nature: A multi-stakeholder perspective on integrated floodplain management. Journal of Environmental Management, 128, 1033-1042.

Gomez, B. (2006). The potential rate of bed-load transport. Proceedings of the National Academy of Sciences U S A, 103, 17170-17173.

Goudie, A. \& Viles, H. (2010). The changing landscapes, Chap. 1. In A. Goudie \& H. Viles (Eds.), Landscapes and geomorphology: A very short introduction. Oxford: Oxford University Press. 
Graf, W. L. (2005). Physical integrity of rivers. In A. S. Goudie (Ed.), Encyclopedia of geomorphology (pp. 779-781). Dordrecht: Springer.

Graf, W. L. (2006). Downstream hydrologic and geomorphic effects of large dams on American rivers. Geomorphology, 79, 336-360.

Gregory, K. J. (2006). The human role in changing river channels. Geomorphology, 79, 172-191.

Guccione, M. J., Meuller, K., Champion, J., Shepherd, S., Carlson, S. D., Odihiambo, B., \& Tate, A. (2002). Stream response to repeated coseismic folding, Tiptonville dome, New Madrid seismic zone. Geomorphology, 43, 313-339.

Hesselink, A. W. (2001). History makes a river. PhD thesis Utrecht University, Utrecht.

Hudson, P. F., Middelkoop, H., \& Stouthamer, E. (2008). Flood management along the lower Mississippi and Rhine Rivers (The Netherlands) and the continuum of geomorphic adjustment. Geomorphology, 101, 209-236.

Kalweit H. (1993). Der Rhein unter der Einwirkung des Menschen: Ausbau, Schiffahrt, Wasserwirtschaft. Bericht Internationale Kommission für die Hydrologie des Rheingebietes, I-11. KHR, Lelystad.

Knight, J. (2012). Development of palimpsest landscapes. Vignettes:Key concepts in geomorphology. http://serc.carleton.edu/68942. Accessed 4 Oct 2014.

Knighton, D. (1998). Fluvial forms and processes - A new perspective (p. 383). London: Arnold.

Kondolf, G. M. (2012). The Espace de Liberte' and Restoration of Fluvial Process: When can the river restore itself and when must we intervene? Chap. 18. In P. J. Boon \& P. J. Raven (Eds.), River conservation and management. Hoboken: Wiley.

Meade, R. H. \& Moody, J. (2010). Causes for the decline of suspended-sediment discharge in the Mississippi River system, 1940-2007. Hydrological Processes, 24, 35-49.

Middelkoop, H., Erkens, G., \& Van der Perk M. (2010). The Rhine delta—a record of sediment trapping over time scales from millennia to decades. Journal of Soils and Sediments, 10, 628-639.

National Research Council. (1995). Flood risk management and the American river basin: An evaluation. water science and technology board, division on earth and life studies. Washington, D.C.: National Academies.

National Research Council. (2005). The science of instream flows: A review of the Texas instream flow program. Committee on review of methods for establishing instream flows for Texas rivers. Water science and technology board, division on earth and life studies. Washington, D.C.: National Academies.

Nienhuis, P. H. (2008). Environmental history of the Rhine-Meuse Delta. An ecological story on evolving human-environmental relations coping with climate change and sea-level rise. Nijmegen: Springer Science.

Nittrouer, J. A., Best, J. L., Brantley, C., Cash, R. W., Czapiga, M., Kumar, P., \& Parker, G.. (2012). Mitigating land loss in coastal Louisiana by controlled diversion of Mississippi River Sand. Nature Geoscience, 5, 534-537.

Schumm, S. A. (1991). To interpret the earth. Ten ways to be wrong. Cambridge: Cambridge University Press.

Syvitski J. P. M, Vörösmarty C. J., Kettner A. J., \& Green P. (2005). Impact of humans on the flux of terrestrial sediment to the global coastal ocean. Science, 308, 376-380.

U.S. Army Corps of Engineers. (2012). Room for the river. Mississippi river commission, Vicksburg, MS. p. 32.

Von Elverfeldt, K. (2012). Fifth problem area: Complexity and non-linearity. Chap. 5. In System theory in geomorphology: Challenges, epistemological consequences and practical implications (pp. 85-90). New York: Springer. doi:10.1007/978-94-007-2822-6

Walter, R. C.,\& Merritts, D. J. (2008). Natural streams and the legacy of water-powered mills. Science, 319(5861), 299-304. doi:10.1126/science.1151716 